\title{
Dampak Pandemi Covid-19 Bagi Komunikasi Publik dan Politik: Studi Deskriptif Pentingnya Syiar Dakwah dalam Keluarga
}

\section{(The Impact of the Covid-19 Pandemic for Public Communication and Politics: A Descriptive Study of the Importance of Da'wah in the Family)}

\author{
Baharuddin $^{1 凶}$, Zulkarnain $^{2}$, M. Anzaikhan ${ }^{3}$ \\ ${ }^{1}$ Program Studi Komunikasi dan Penyiaran Islam, Universitas Islam Negeri Ar-Raniry, Indonesia \\ ${ }^{2}$ Program Studi Komunikasi dan Penyiaran Islam, Institut Agama Islam Negeri Langsa, Indonesia \\ ${ }^{3}$ Program Studi Hukum Keluarga Islam, Institut Agama Islam Negeri Langsa, Indonesia \\ $凶_{\text {email: baharuddin.arraniry@ac.id }}$
}

\begin{tabular}{ccc}
\hline First received: & Revised: & Final Accepted: \\
21 October 2021 & 16 November 2021 & 21 December 2021 \\
\hline
\end{tabular}

\begin{abstract}
The Covid-19 pandemic has had a negative impact on various aspects of human life, starting from the dimensions of health, economy, education, tourism, culinary, politics, public policy, even the dimension of monotheism. Covid-19 is not just a local disaster, it has become a 'pandemic' which means a global-scale emergency status. Millions of people have died, and countless bave been affected in various aspects. Handling Covid-19 is closely related to communication carried out by each element. Be it political communication, public communication, da'wah communication, and so on. Communication is basically neutral, depending on where users take advantage of developing issues. Regarding the Covid-19 pandemic, communication is often used as a medium to make things worse. This difficult situation is used by certain parties to gain political advantage by spreading hoax news and hate speech against the government's handling of Covid-19. This research is classified as literature research with a qualitative approach. The methodology used is a descriptive study of various communication themes during a pandemic. Such as monotheism communication, family communication, public communication, and political communication. The results of the study concluded several things; First, positive communication that supports government programs if it is considered good and useful for overcoming the Covid-19 pandemic outbreak. This party will usually implement various policies such as lockdown, PSBB, social distancing, health protocols, and vaccinations. Second, is negative communication that rejects various government programs for political interests (contrary to the current government). Usually, this group will spread hoaxes and hate speech against the government's Covid-19 handling policies. These circles do not view information objectively, but look. for loopholes to attack. various weaknesses in government programs in order to influence the wider community.
\end{abstract}

Keywords : Communication; Covid-19; The Impact of the Pandemic; Political; Family.

\section{ABSTRAK}

Pandemi Covid-19 berdampak buruk pada berbagai sendi kehidupan manusia, mulai dari dimensi kesehatan, ekonomi, pendidikan, wisata, kuliner, politik, kebijakan publik, bahkan dimensi tauhid. Covid-19 bukan sebatas bencana lokal, ia sudah menjadi 'pandemi' yang berarti status darurat berskala global. Jutaan manusia sudah menjadi korban jiwa, dan tak terhitung jumlahnya bagi yang terkena dampak dalam berbagai aspek. Penanganan Covid-19 erat kaitannya komunikasi yang dilakukan setiap elemen. Baik itu komunikasi politik, komunikasi publik, komunikasi dakwah, dan lain sebagainya. Komunikasi pada dasarnya bersifat netral, tergantung kemana pengguna memanfaatkan isu yang berkembang. Terkait pandemi Covid-19, sering kali komunikasi digunakan sebagai media memperkeruh keadaan. Situasi sulit dimanfaatkan oleh pihak-pihak tertentu untuk meraih keuntungan politis dengan menyebarkan berita-berita hoaks dan ujaran kebencian terhadap penanggulangan Covid19 oleh pemerintah. Penelitian ini tergolong dalam penelitian pustaka dengan pendekatan kualitatif. Adapun metodologi yang digunakan adalah studi deskriptif terhadap berbagai tema-tema komunikasi di masa pandemi. Seperti komunikasi tauhid, komunikasi keluarga, komunikasi publik, dan komunikasi politik. Hasil penelitian menyimpulkan beberapa hal; Pertama, komunikasi positif yang mendukung 
program pemerintah jika itu dianggap baik dan bermanfaat bagi penanggulangan wabah pandemi Covid-19. Pihak ini biasanya akan melaksanakan berbagai kebijakan seperti lockdown, PSBB, sosial distancing, protokoler kesehatan, dan vaksinasi. Kedua, adalah komunikasi negatif yang menolak berbagai program pemerintah atas kepentingan politik (kontra dengan pemerintah saat ini). Biasanya, kalangan ini akan menyebarkan hoaks dan ujaran kebencian terhadap kebijakan penanganan Covid-19 yang dijalankan pemerintah. Kalangan ini tidak melihat informasi secara objektif, melainkan mencaricari celah untuk menyerang berbagai kelemahan dalam program pemerintah guna mempengaruhi masyarakat luas.

Kata kunci : Komunikasi; Covid-19; Dampak Pandemi; Politik; Keluarga.

\section{PENDAHULUAN}

Dunia benar-benar diberi panik oleh sebuah bencana lokal yang tiba-tiba mendunia. Virus Corona yang kemudian populer disebut Covid-19.Wabah ini tanpa wujud (abstrak) tetapi seolah-olah nyata. Hal ini terlihat sistematis, komprehensif, holistik, dan menyerang berbagai lini. Tidak hanya pada aspek kesehatan dan ekonomi, kini ia juga sudah menyerang dimensi psikologi manusia. Hal tersebut erat kaitannya dengan eksistensi Covid-19 itu sendiri yang terus menyebar tanpa menunjukkan tanda-tanda kepergiannya (Freiling et al. 2021). Belum lagi masih lemahnya penanganan pihak terkait, minimnya alat pendeteksi (rapid tes dan sebagainya) ditambah maraknya berita hoax yang kontroversi, membuat masyarakat semakin panik dan tidak tahu arah menyikapi situasi yang kian mencekam.

Tidak sedikit masyarakat yang sudah mengalami gejala 'phobia corona'. Hal itu ditandai dari rasa takut dan enggan berobat ke pihak medis ketika mengalami penyakit yang kebetulan memiliki kondisi yang mirip dengan gejala Covid-19. Ketika tubuh demam tinggi, sebisa mungkin masyarakat akan mencoba mengobatinya dengan jalur alternatif seperti obat herbal dan memperbanyak istirahat (Rahmawati, Rahadi, and Putri 2021). Begitu juga saat batuk, masyarakat lebih memilih mengurung diri di rumah karena khawatir dicurigai mengidap dan membawa virus ke teman-teman yang lain. Padahal, terkadang itu merupakan sakit batuk biasa karena terlalu banyak mengkonsumsi makanan dingin atau makanan berminyak. Namun inilah yang terjadi saat ini, gejolak Covid-19 sudah seperti phobia sehingga penyakit yang ada coba disembunyikan kecuali dalam kondisi sudah tidak tertahankan lagi. Semua itu tak terlepas dari komunikasi publik yang beredar, baik itu secara alamiah ataupun diseting oleh oknum-oknum pemangku kepentingan.

Pada kasus yang lain, ada individu yang memiliki riwayat sakit asam lambung. Biasanya, kalau asam lambungnya kumat maka ia akan demam tinggi dan konsultasi dengan dokter. Namun, ketika melihat pintu masuk puskemas sudah ada pihak panitia yang mengecek suhu tubuh, ia enggan melanjutkan pengobatan dan lebih memilih pulang untuk membeli obat kampung. Ini terkesan sepele, tapi sadar atau tidak banyak dialami oleh masyarakat khususnya mereka yang berada ditaraf garis ekonomi menengah ke bawah (Wahyu et al. 2021).

Maka tidak heran, jika Warga Kampung Ciloang, Kelurahan Sumur Pecung, Kota Serang, Indonesia kabur ketika diumumkan akan dilakukan rapid tes masal. Warganya menghilang (pergi) menjelang hari yang telah ditentukan. Desa ini sepintas terlihat seperti kota mati dimana semua pintu dikunci dan digembok dari luar (McGuire et al. 2020). Fenomena ini tentu menjadi sebuah renungan, mengapa mereka pergi? Apakah karena mereka sehat atau justru mereka sudah terpapar virus? Ternyata, sebelum mereka dipastikan sakit atau tidak, lebih dulu sudah ada penyakit yang menggerogoti yakni phobia corona.

Kecemasan dan ketakutan masyarakat akan sesuatu yang bersinggungan dengan Corona memang cukup beralasan. Hal tersebut dikarenakan masih ada oknum-oknum nakal yang ikut menyulut api di tengah kepanikan. Entah apa modusnya, mereka sengaja mempelintir informasi dengan berbagai kabar tak sedap sehingga rusaknya kepercayaan masyarakat terhadap pihak medis (Serfontein 2021). Padahal sebelumnya, pihak medis adalah 
etnis yang paling dihormati bahkan disebut-sebut sebagai pahlawan karena menjadi garda terdepan dalam penanganan Covid-19.

Namun, gara-gara segelintir oknum yang tak bertanggung jawab. Kepercayaan itu seakan rusak. Di Pasuruan, Jambi Misalnya, kedapatan pihak rumah sakit yang dengan sengaja membuat laporan pasiennya terjangkit Covid-19 karena ingin memperoleh insentif (dana 90 jutaan) dari pemerintah. Begitu juga informasi yang beredar, bahwa ada pasien yang diklaim Corona namun setelah dibuka paksa oleh keluarga, ternyata tubuh pasien sudah diambil organ pentingnya. Ini tentu kabar yang menyakitkan jika benar, namun sebaliknya justru fitnah yang besar jika informasi nya ternyata hoax (Mansyur 2020).

Dampak dari informasi di atas, terlepas fakta atau bukan yang jelas beredar di tengahtengah masyarakat. Akibatnya, kini berkembang dimana-mana kelompok yang menggembargemborkan bahwa sesungguhnya Covid-19 itu tidak ada dan hanya permainan pihak pemerintah saja. Sungguh ini adalah sikap yang keliru dan akan memperburuk situasi. Belum lagi ada kalangan yang mempolitisasi pandemi Covid-19 (Kastolani 2020), menggunakan kesempatan ini sebagai upaya meraih simpatisan masyarakat. Bentuk politis yang lain, menyerang berbagai kebijakan pemerintah agar terdengar buruk bagi masyarakat untuk panggung demokrasi kedepan.

Kajian tentang pandemi Covid-19 bukanlah perkara baru, Syaipuddin dalam jurnalnya "Efektifitas Media Komunikasi di Tengah Pandemi: Respon Gugus Tugas Percepatan Penanganan Covid19 Kabupaten Tulungagung," menjelaskan dengan sangat baik bagaimana komunikasi berperan penting dalam penanganan wabah Covid-19 (Syaipudin 2020). Begitu juga dengan Akbar, dalam artikelnya yang berjudul; "Media Komunikasi dalam Mendukung Penyebarluasan Informasi Penanggulangan Pandemi Covid-19," membahas dengan terperinci berbagai platform media komunikasi yang berperan penting dalam penanggulangan Pandemi (Akbar 2021). Selain itu, ada juga Indasari dan Anggraini dengan artikel mereka; "Krisis Komunikasi Pada Masa Pandemi Covid-19 (Studi Kasus Pemberitaan Penyebaran Covid-19 Melalui Udara).” Artikel ini memuat media komunikasi yang kerap disalah artikan oleh oknum-oknum tertentu sehingga membuat Pandemi Covid-19 semakin menakutkan bagi masyarakat.

Semua penelitian di atas, pada umumnya hanya terfokus pada penggunaan komunikasi di tengah pandemi. Tidak ada yang membuat kajian berupa deskripsi antara dakwah dan politik dengan tema syiar dakwah di lingkungan keluarga. Maka dari itu, berdasarkan beberapa artikel dan penelitian sebelumnya, sejauh observasi dan pengamatan penulis, artikel dengan judul Dampak Pandemi Covid-19 Bagi Komunikasi Publik dan Politik: Studi Deskriptif Pentingnya Syiar Dakwah dalam Keluarga, memiliki novelty dan keunikan.

\section{METODE PENELITIAN}

Penelitian ini tergolong dalam penelitian pustaka dengan pendekatan kualitatif (Sonata 2015). Adapun metodologi yang digunakan adalah studi deskriptif terhadap berbagai tema-tema komunikasi di masa pandemi. Seperti komunikasi tauhid, komunikasi keluarga, komunikasi publik, dan komunikasi politik. Penulis juga mencari data-data tentang fenomena Covid-19 di lapangan melalui literasi. Pendekatan ini dianggap cocok mengingat pandemi Covid-19 berbicara tentang kejadian di lapangan yang menerapkan pengalaman seseorang. Sumber data pada penelitian ini adalah kajian literasi berdasarkan temuan-temuan lapangan terkait relevansi antara komunikasi publik dan pandemi Covid-19. Sumber primer dalam tulisan ini adalah jurnal-jurnal terakereditasi yang membahas dan mengkaji pandemi Covid-19 dalam pandangan dakwah, komunikasi, dan politik. Sumber sekunder atau pendukung lainnya adalah opini publik figur yang fenomenal dan terkait dengan wacana penulis.

Metode analisis data pada tulisan ini bersifat komparasi antara satu sumber dan sumber lainnya. Metode ini dianggap penting mengingat banyak penelitian tentang Covid-19 yang variatif dan tidak relevan khususnya bila dilakukan dalam pendekatan komunikasi politik. Saat 
melakukan verifikasi data, penulis membagi dua tema utama yaitu Covid-19 dan komunikasi politik. Setelah data dikumpulkan maka akan melakukan berbagai filterisasi terkait zonasi dan signifikasinya dengan topik penelitian. Berhubung tulisan ini memiliki zonasi pada lokasi tertentu di Indonesia, maka penulis juga melakukan observasi pada wilayah-wilayah, baik yang bersifat pustaka maupun lapangan.

\section{HASIL PENELITIAN DAN PEMBAHASAN Pandemi di Indonesia}

Pandemi Covid-19 adalah wabah penyakit menular yang terjangkit dengan cepat dan menimbulkan banyak korban. Pada akhir tahun 2019, dunia digemparkan dengan adanya wabah jenis baru yang tidak diketahui. Kasus tersebut berasal dari kota Wuhan, China. Penyakit ini dapat menyebar pada manusia dan hewan. Gejala awal wabah ini biasanya menyerang saluran pernafasan hingga dapat menyebabkan sindrom pernafasan yang berat. Penyebaran wabah ini pun terjadi sangat cepat dan banyak memakan korban. Hari demi hari Organisasi Kesehatan Dunia telah menetapkan bahwa wabah ini merupakan Coronavirus yang bisa menyebabkan gangguan sistem pernafasan ringan, infeksi paru-paru berat, hingga sampai kematian. virus ini semakin lama semakin meningkat dan berkembang pesat, sehingga wabah ini disebut sebagai Pandemic Global karena dengan waktu yang sangat singkat telah menyebar pada sekuruh penjuru dunia termasuk Indonesia (Indasari and Anggriani 2020).

Kasus positif Covid-19 di Indonesia mencapai 4.252.705 orang, jumlah kasus sembuh 4.100.837 orang, serta 143.714 orang kasus kematian. Hingga saat ini, masyarakat Indonesia masih banyak yang tidak memiliki kesadaran akan berbahaya nya wabah ini. Gejala awalnya berupa demam, batuk kering, serta sesak nafas. Penyebaran wabah ini rentan terjangkit oleh orang-orang yang berusia lanjut yang sudah memiliki penyakit bawaan, serta anak-anak karena memiliki imun yang lemah. Cara penyebaran wabah ini melalui percikan dari hidung atau mulut ketika bersin. Oleh karena itu, masyarakat dianjurkan untuk memakai masker, mencuci tangan, dan menjaga jarak (Nasution et al. 2021). Pemerintah Indonesia sendiri tidak tinggal diam, mereka merespon akan bahaya nya wabah ini sehingga membuat beberapa kebijakan agar dapat memutuskan mata rantai penyebara covid-19. Kebijakan tersebut seperti social distancing, physical distancing, serta Perbatasan Sosial Berskala Besar.

\section{Kebijakan Pemerintah sebagai Komunikasi Publik dan Politik}

Salah Satu kebijakan yang sangat popular dilakukan oleh Pemerintah adalah Perbatasan Sosial Berskala Besar (PSBB). Ini merupakan sebuah kebijakan yang bertujuan untuk memutskan mata rantai penyebaran Covid-19 dan menekan angka kematian berlanjut. Walaupun ada beberapa fasilitas yang bersifat umum ditutup. Akan tetapi, ada beberapa fasilitas yang bersifat urgen yang tetap dibuka selama PSBB seperti rumah sakit, dan minimarket. Pemerintah sangat mengharapkan agar masyarakat dapat ikut berkontribusi dan mendukung kebijakan ini (Nasruddin and Haq 2020). Namun fakta yang terjadi di lapangan sangat berbeda dengan apa yang diharapkan. Masih banyak masyarakat yang tidak mengikuti anjuran dari pemerintah. Hal demikian bukan keinginan mereka yang dengan sengaja tidak mendukung kebijakan dari pemerintah tetapi keadaan yang membuat mereka untuk tidak berdiam dirumah karena mayoritas masyarakat Indonesia bekerja sebagai petani, kuli bangunan, pedagang kaki lima, tukang ojek, dan lainya.

Reaksi masyarakat dalam menanggapi upaya pemerintah untuk memutuskan mata rantai penyebaran wabah ini beranekaragam. Banyak masyarakat yang mengeluh akibat dampak yang dialami ketika masa PSBB seperti sulit nya ekonomi karena tidak bisa bekerja seperti biasanya, perasaan yang ber;lebihan akibat khawatir akan wabah ini. Masalah lain yang terjadi yaitu menurunya pendapatan masyarakat yang mengakibatkan turunya daya beli. Maksudnya, masyarakat tidak mampu membeli bahan kebutuhan sehari-hari, tidak mampu 
membayar kredit, dan lain sebagainya. Meskipun kebijakan ini memiliki dampak besar bagi masyarakat, akan tetapi harus dilakukan agar memutuskan mata rantai penyebaran wabah ini dan menekan angka kematian akibat covid-19. Selanjutnya, ditengah kondisi yang kritis tersebut, masih ada segelintir oknum yang dengan sengaja mempersulit situasi dengan menyebarkan berita hoaks dan ujaran kebencian.

Selain dalam bidang ekonomi, PSBB juga memiliki dampak dalam bidang transportasi. Semua transportasi ditutup, mulai dari mobil, motor, kereta api, hingga pesawat. Kemudian tidak dibolehkan keluar rumah, tidak pergi ke kantor, dan PHK dimana-mana. Oleh sebab itu, hal ini membutuhkan kesadaran bagi apparat kepolisian bahkan masyarakat. Namun hal tersebut tidak lah mudah karena kondisi finansial masyarakat yang kurang mendukung. Oleh karena itu, sebelum melakukan kebijakan yang memiliki dampak besar bagi masyakarat, negara telah membuat berbagai kebijakan tentang perubahan anggaran negara, meningkatkan dana sosial, perpanjangan batas akhir pajak, serta memastikan anggaran sembako dan BLT untuk memenuhi kebutuhan masyarakat (Ngadi, Meliana, and Purba 2020).

Sejauh ini, dukungan dari masyarakat sangat dipengaruhi oleh komunikasi yang dijalankan pemerintah atau lawan politiknya. Program vaksin misalnya, berbagai isu negatif dan ujaran kebencian beredar dimana-mana (Kastolani 2020). Bahkan, kelainan akibat proses vaksin seperti lumpuh, alergi, kematian, dan lain sebagainya lebih muncul dipermukaan media meskipun secara kuantitatif jumlahnya sangat jauh dibandingkan kalangan yang baik-baik saja setelah divaksinasi. Ini menjadi salah satu bukti bahwa komunikasi negatif (hoaks) masih menjamur dibelahan bumi Indonesia.

Dampak dari hoaks dan ujaran kebencian terkait pandemi tidak bisa dipandang sebelah mata, berdasarkan laporan pihak berwajib, hoaks dan ujaran kebencian tidak murni terjadi secara kebetulan (alamiah). Melainkan terjadi karena ada pihak tertentu yang terstruktur dan terorganisir menggerakkan masa dan media komunikasi untuk mensosialisasikan berita hoaks dan ujaran kebencian. Alasan utamanya adalah karena kepentingan politis yang menginginkan citra pemerintah memburuk. Lebih dari itu, ada upaya untuk menjadikan penanganan Covid19 sebagai strategi jitu dalam memenangkan Pilkada atau Pemilu kedepan.

\section{Covid-19 dalam Gesekan antara Dakwah dan Politis}

Karakter masyarakat Indonesia selaku mayoritas muslim, tentu kental akan nuansa ibadah berjamaah sehingga sering adanya temuan menentang kebijakan Lockdown Pemerintah. Shalat Jum'at misalnya, merupakan salah satu media ibadah yang dihuni oleh banyak orang. Meskipun pihak MUI sudah memfatwakan bahwa shalat Jum'at pada momen maraknya Covid-19 bisa digantikan dengan shalat Dzuhur dirumah, tentu masih ada oknum yang tidak sepakat dengan ini (Mushodiq and Imron 2020). Bahkan mereka senantiasa mendakwahkan bahwa; "Manusia jangan takut kepada Corona dibandingkan takut kepada Allab".

Bagi orang awam, jika segala sesuatu disandingkan dengan paradigma agama semuanya akan menjadi sensitif. Padahal, kebijakan menghindari keramaian (termasuk shalat Jum'at) adalah bentuk ihtiar manusia dalam menjaga kesehatan dan kehidupan. Bukankah jika berwudhu (dengan air) jika dikhawatirkan bisa memperburuk kesehatan maka dibolehkan tayamum? Lantas mengapa menghindari shalat berjamaah dengan alasan kesehatan mesti diperumit? Allah Swt maha tahu dengan segala kondisi hambanya, Islam tidak pernah mempersulit, selalu ada kemudahan pada beragam kondisi dan keadaan. Begitu juga dalam menyikapi wabah Corona yang sudah jelas mengancam kesehatan dan dan kehidupan.

Setiap muslim sepakat bahwa takdir hidup dan mati tidak bisa diubah, semuanya sudah digariskan dan tercatat. Namun jangan lupa, manusia tidak pernah tahu apa yang dituliskan, itu murni rahasia Allah. Tugas manusia adalah berikhtiar semaksimal mungkin, masalah hasil baru kemudian dipasrahkan ke pada sang khaliq (Anzaikhan 2021). Terkait wabah sekaliber Corona ini, tidak perlu diperkeruh dengan membandingkannya ke wilayah aqidah. Stop isu-isu yang 
akan menuai kontroversi di masyarakat yang terletak diantara dakwah dan politis, seperti; "Manusia lebih takut dengan Corona dibandingkan Tuban", "Setan dan Corona tertawa karena berhasil mengalabkan umat muslim untuk tidak berjamaah dan bersosial", "Corona adalah penyakit kutukan, dan hanya orang yang tidak lurus imannya yang akan terpapar."

Pernyataan di atas tentu harus dievaluasi dengan bijak, negeri ini tengah disibukkan dengan masalah virus baru yang mematikan. Harus saling bekerjasama untuk mengantisivasi bukan memancing di air keruh guna mencari popularitas belaka atau kepentingan politik (Anzaikhan 2019). Pernah juga bermunculan berbagai komunitas khusus yang memiliki tujuan tidak realistis, salah satunya adalah gerakan 'SPK' (Stop Posting Korona). Sebuah gerakan yang eksis dimedia sosial Indonesia guna mengajak masa untuk tidak mengindahkan kebijakan pemerintah khususnya dalam menjauhi keramaian dengan motif ibadah dan silaturrahmi. Termasuk oknum gubernur yang mencoba mempolitisir wabah Corona untuk memperoleh simpatisan masyarakat dengan mengatakan; "Jangan tinggalkan mesjid karena takut Corona." Statemen ini memiliki dualisme makna (dakwah atau politis) tergantung niat yang mengutarakan.

Padahal, Nabi Muhammad Saw pernah bersabda; "Jaubilah orang yang terkena lepra (penyakit menular) seperti kamu menjaubi singa." Shalat berjamaah memang wajib, silaturrahmi juga bagus, namun Islam adalah ajaran yang bermakna 'selamat', itu maknanya Islam sangat mentolerir dan memberikan kemudahan dalam pelaksanaan syariat jika itu dilakukan dalam kondisi darurat. Saat berpergian jauh misalnya, shalat boleh dijamak atau diqadha (Saputera 2020). Saat sakit, sholat boleh dilakukan dengan cara duduk atau berbaring, saat berperang kiblat shalat boleh menghadap pada arah dimana musuh diprediksi akan datang. Masih banyak kemudahan beribadah dalam Islam yang tidak harus mengancam kesehatan apalagi virus Corona yang sudah jelas sudah terbukti merengut banyak nyawa.

Pada intinya, pemerintah (oknum politis) dan tokoh agama (oknum pendakwah) harus bersatu padu dalam merumuskan kebijakan untuk masyarakat terkait Covid-19. Seringkali semua itu menjadi sulit karena ketiga elemen ini berbeda pandangan satu sama lain. Ketika Pemerintah menerapkan lockdown di mesjid misalnya, tokoh agama atau adat menantang itu dan membuat opini yang berbeda dengan otoritas Pemerintah (Nasution et al. 2021). Akibatnya, masyarakat terpecah belah menjadi banyak kubu. Satu sisi adalah kalangan yang percaya akan pemerintah dan menjalankan protokol medis, satu sisi lagi adalah kalangan yang tidak percaya bahwa Covid-19 itu ada dan menganggapnya sebagai politisasi Pemerintah.

\section{Komunikasi Terkait Covid-19 oleh MUI}

Demi menghadapi wabah pandemi dari Covid-19 dan membantu gerakan pemerintahan melakukan social-distancing tetap berjalan dengan baik, dan demi mengurangi menyebarnya virus dari Covid-19 ini, maka Majelis Ulama Indonesia (MUI) menertibtkan putusan No. 14 pada tahun 2020 tentang pelaksanaan Ibadah pada masa pandemi Covid-19 (Fahiza and Siti Nur Zalikha 2021). Mengenai putusan dari MUI yang telah menjadi suatu perdiskusian di dalam lingkungan umat muslim (Indonesia) yang berhubungan dengan pelaksanaan sholat berjamaah dan sholat jumat, sebagai berikut:

\section{Pada point ke-2}

Seseorang yang telah terkena virus dari virus Corona, harus mengisolasi dan menjaga dirinya supaya virus ini tidak menular kepada orang sekitarnya. Bagi dirinya seperti sholat Jumat bisa digantikan dengan sholat dzuhur, karena sholat Jumat itu adalah suatu ibadah yang harus (wajib) dan menyertakan banyak orang, oleh karena itu kemungkinan terjadinya penularan virus ini bisa ke banyak orang (Junaedi, Aliyudin, and Sutisna 2020). Bagi dirinya itu haram (tidak diperbolehkan) melakukan kegiatan ibadah sunnah yang memberikan kemungkinan terjadinya penularan, salah satunya seperti sholat berjama'ah 5 waktu/rawatib di masjid, sholat 
Tarawih di masjid serta idul fitri dan adha di masjid ataupun tempat umum lainnya, dan tidak boleh menghadirkan diri pada pengajian umum atau ceramah dan tabligh akbar (besar).

\section{Pada point ke-3a dan ke-3b}

Orang yang memiliki raga yang bugar dan yang tidak diketahui atau dipercayai tidak terdampak Covid-19, harus melihat beberapa hal, yaitu: Pertama, zona merah. Pada kondisi ini, individu berposisi pada suatu tempat yang memiliki peluang yang mana penularannya berpotensi sangat tinggi ataupun tinggi. Bersumber pada keputusan dari pihak yang berkuasa maka dari itu, seorang individu diperbolehkan melewati sholat Jumat pada hari Jumat dan memindahkannya dengan cara menunaikan sholat dzuhur pada posisi kediamannya berada, kemudian tidak melakukan sholat secara berjama'ah pada sholat 5 waktu atau rawatib, tarawih di masjid, dan sholat hari raya idul fitri dan adha di masjid atau pada tempat yang ada keramaian orang (Saputera 2020).

Kedua, Zona kuning atau hijau. Pada kondisi ini, individu berposisi pada suatu tempat yang memliki peluang yang mana penularannya berpotensi rendah. Bersumber pada keputusan dari pihak yang berkuasa maka dari itu, setiap individu wajib menunaikan suatu kewajiban ibadah seperti hari-hari biasanya dan harus bisa menjaga dirinya supaya tidak terjangkit wabah dari Covid-19, salah satu contohnya dengan cara seperti tidak melakukan kontak fisik (tubuh) secara langsung, membawa peralatan sholat sendiri, dan setiap harinya membasuh tangannya dengan sabun (Fahiza and Siti Nur Zalikha 2021).

\section{Pada point ke-4}

Pada keadaan menyebarnya wabah dari Covid-19 tidak terkontrol di suatu tempat yang membahayakan nyawa, umat muslim tidak diperbolehkan mengadakan sholat Jumat pada hari Jumat di tempat tersebut, sampai kondisi menjadi sedia kala kembali dan harus menggantikan sholatnya tersebut dengan sholat dzuhur di tempat kediamannya sendiri (Fahiza and Siti Nur Zalikha 2021). Selain itu juga tidak diperbolehkan mengadakan kegiatan ibadah yang menyeret orang dalam jumlah yang banyak dan dipercayai bisa menjadi sebuah media bagi penyebaran dari Covid-19 ini, contohnya seperti sholat berjama'ah pada sholat lima waktu atau rawatib, sholat Tarawih dan sholat hari raya di masjid atau kawasan yang terbuka lainnya, dan tidak menghadirkan diri pada pengajian yang terbuka dan majelis-majelis taklim.

\section{Pada point ke-5}

Pada keadaan menyebarnya wabah dari Covid-19 yang terkontrol, umat muslimin harus mengadakan sholat Jumat dan boleh mengadakan kegiatan ibadah yang menyeret banyak orang, contohnya seperti sholat berjama'ah pada sholat 5 waktu atau sholat rawatib, sholat Tarawih dan sholat di hari raya di masjid atau tempat yang terbuka lainnya, dan boleh menghadirkan diri pada pengajian yang terbuka dan majelis-majelis taklim dengan cara harus menjaga dirinya supaya tidak terjangkit wabah dari Covid-19 ini (Junaedi et al. 2020).

Mengerjakan shalat secara berjamaah di rumah Allah Swt ialah sebuah ajakan dan contoh daripada Rasulullah Saw untuk para kaum laki khususnya, maka penghapusan shalat secara berjamaah di masjid pada masa wabah dari covid-19 ini memperoleh sangat banyak kecaman dari warga (indonesia), adanya pihak yang mendukung dan ada juga pihak yang menentang dalam menghadapi usulan dari pemerintah ini, dikarenakan dianggap terlalu berlebihan dengan pemerintah menutup rumah Allah dari kegiatan ibadah. Pada intinya kasus penyebaran wabah dari covid 19 ini jika dipahami lebih lanjut ialah suatu ujian dari keseimbangan ilmu dalam keislaman dan dengan ilmu sains, tidak membingungkan jikalau terjadinya pola pikir yang tidak sama dalam menghadapi usulan tentang sholat di rumah sendiri dari pemerintah dan Majelis Ulama Indonesia (Ngadi et al. 2020). 
Pada salah satu masjid di Jawa Barat yaitu masjid Jami Al-Azhar Jakapermai, kegiatan peribadahan kembali dibuka pada waktu tepatnya pada tanngal 27 bulan April pada tahun 2020 silam setelah ditutup guna melakukan aktivitas shalat secara berjamaah dan pengajian tentang Islam sejak tanggal 27 bulan Maret pada tahun 2020 silam, pelaksanaan peribadahan, baik itu shalat Jumat maupun shalat rawatib pada masjid Al-Azhar mematuhi aturan kesehatan yang di usulkan oleh pemerintah, sebagaimana yang dikatakan oleh kepala (pemimpin) rumah tangga (RT) di masjid Jami Al-Azhar Jakapermai, beberapa aktivitas peribadahan dengan menerapkan aturan kesehatan, salah satunya yaiut shalat hari raya yaitu Idul Fitri $1441 \mathrm{H}$ silam (Fahiza and Siti Nur Zalikha 2021).

Pada saat melakukan shalat idul fitri setelah memperolah izin dari satgas Covid Yayasan Wakaf Al-Muhajirien dengan jemaah yang dibatasi, karena itu khutbah dari shalat idul fitri diberitakan melalui media televisi yaitu siaran MJAtv, sehingga para jemaah yang sedang berada di rumah bisa ikut mendengarkannya juga, yaitu dengan cara membukan siaran televisi yaitu pada siaran MJATv (Nasution 2020). Pelaksanaan dari shalat idul fitri kemudian khutbah yang diberitakan melalui aplikasi youtube sangat efektif, mengingat akan adanya sebuah larangan utuk berkumpul di masjid secara ramai. Demikian daripada itu dengan cara pelaksanaan shalat jumat pada hari jumat yang telah kembali dilakukan pada tanggal 1 tepatnya pada bulan Mei tahun 2020 setelah dihilangkan dan diusulkan melakukan sholat di rumah pada tanggal 27 Maret 2020 (Sarnoto, Hidayat, and Rahmawati n.d.). Semua itu tak terlepas dari media komunikasi dalam penerapan sholat dan pentingnya komunikasi agar program dan kebijakan pemerintah diterima oleh masyarakat.

\section{Pandemi dalam Komunikasi Tauhid}

Tauhid adalah meyakini bahwa Allah merupakan satu-satu Rabb yang menciptakan, menguasai, memelihara, dan mengatur alam semseta dan menjadikan Allah satu-satunya tempat untuk ibadah seperti shalat, berdoa, takut, berharap, dan lain-lainya. Tauhid merupakan aqidah bawaan manusia. Pada hakikatnya manusia harus melihat bahwa mereka itu berasal dari Allah swt bukan dari lainya. Manusia mestinya melihat bahwa nasib baik, buruk, untung, dan rugi semata-mata berawal dan berasal dari Allah swt. Kemudian manusia menyembah sematamata hanya kepada Allah swt tanpa terkecuali. Hasil dari tauhid itu sendiri yaitu berserah diri kepada Allah swt. Tidak mengeluh pada makhluk lainya (Setiawan 2016). Hanya saja bersikap ridho terhadap ketentuan Allah swt. Pengakuan tersebut tidak cukup menjadikan seseorang beriman kepada Allah swt. Tetapi desertai dengan mengarahkan segala bentuk perbuatan yang termasuk dalam katagori ibadah, seperti sholat.

Pandemi dapat menyinggung tauhid seseorang. Ada sebagian kalangan mengartikan bahwa pendemi ini hakikatnya adalah azab tuhan, kutukan, ujian, takdir yang diberikan untuk kita, bahkan ada yang tidak percaya akan wabah ini. Mereka yang memiliki dasar agama yang lemah percaya akan desas-desus yang menyesatkan itu. Konspirasi tentang asal-usul wabah ini beredar secara global yang dirangkai dengan ketakutan (panic bulying) (Gustomy 2020). Padahal kondisi ini sudah pernah terjadi ketika zaman nya Rasulullah. Kondisi yang sama, serta penangananya pun sama. Saat itu, Rasulullah memerintahkan orang yang terjangkit wabah menular itu untuk menerapkan karantina (isolasi) dan memerintahkan agar tidak berdekatdekatan atau melihat orang yang terjangkit wabah yang menular tersebut. Untuk memeastikan kebijakan tersebut dijalankan, Rasulullah membangun tembok di sekitar wabah tersebut. Rasulullah juga pernah memerintahkan agar umatnya tidak mendekati wilayah yang terjangkit wabah tersebut. Jika terpapar mereka dilarang untuk keluar (Baidowi et al. 2021).

Terkait masalah pandemi ini, kita sebagai kaum muslimin dan musliman seharusnya selain ikhtiar dalam menyikapi upaya yang dilakukan oleh pemerintah, maka tingkatkanlah spiritual juga. Sebagai muslim kita dapat merenungkan lebih jauh bahwa wabah ini merupakan sebuah rahmat yang diberikan, sebuah peringatan untuk selalu dijadikan jalan tengah atau jalan 
untuk selalu mendekatkan diri kepada sang pencipta. Sehingga, ketika kita berserah diri kepada Allah swt, maka akan dirasakan ketenangan dan dengan segala usaha serta doa keselamatan. Selalu melibatkan Allah swt dalam hal apapun, dan berharap wabah ini akan segera berakhir.

\section{Pandemi dalam Komunikasi Keluarga}

Keluarga merupakan tempat lingkungan paling kecil, yang biasanya teridiri dari dua induvidu atau lebih. Keluarga sebaik-baiknya tempat untuk kembali. Artinya ketika ada masalah diluar sana kita pulang kerumah (Paisal 2021). Keluarga adalah tempat untuk kita beristirahat ketika sudah melakukan kegiatan diluar. Berbeda dengan kondisi pandemi saat ini, kita dituntut untuk melakukan segala aktifitas dirumah. Seperti belajar, ibadah, bahkan bekerja. Keluarga memiliki peran penting dalam kondisi saat ini, dimana lingkungan keluarga menjadi sumber pendidikan utama untuk sesorang dalam menghadapi kehidupannya. Lingkungan keluarga diharapkan dapat memberi edukasi tentang kesehatan dalam mencegah terjangkit wabah ini. Pandemi ini memiliki perubahan dalam berbagai aspek termasuk dalam pendidikan formal seperti sekolah.

Semua sekolah di wajibkan untuk belajar secara daring, tidak tatap muka seperti biasanya untuk menghindari kerumunan. Hal ini membuat Sebagian siswa mengalami kesulitan dalam mengembangkan kemampuan beradaptasi untuk belajar secara daring. Kemampuan tersebut perlu dikembangkan dari lingkungan keluarga. Peran keluarga menjadi lebih luas akibat pembelajaran secara daring (Dessy Asnita 2021). Dalam menjalankan hal tersebut, keluarga harus mampu mendampingi anak, serta membimbing agar pembelajaran secara daring dapat berjalan dengan semestinya. Selain itu, pada situasi pandemic ini keluarga memiliki peran dalam aspek sosial. Menanamkan rasa solidaritas terhadap sesama manusia. Pemerintah menganjurkan kita untuk sosial distancing, namun bukan berarti tidak mau berjabat tangan serta menjauhi orang lain. Hanya saja kondisi saat ini tidak memungkinkan kita untuk tidak menjaga jarak demi memutuskan mata rantai penyebaran wabah ini. Hal tersebut perlu ditanamkan kepada anak tentang konsep menjaga jarak dalam keadaan pandemic saat ini.

Kondisi pandemic seperti ini, seluruh masyarakat dituntut untuk beribadah dirumah. Semua tempat ibadah tidak banyak berperan aktif seperti biasanya guna untuk menghindari kerumunan. Dalam hal ini keluarga memiliki peran dalam edukasi tentang keimanan anggota keluarganya. Pendidikan tentang iman diawali dengan keluarga, sehingga dapat melahirkan angota keluarga yang memiliki hidup yang berkualitas (Roni and Anzaikhan 2021). Hal ini bergantung pada keluarganya, jika keimanan sebuah keluarga nya berkualitas, maka iman anak pun mencerminkan keimanan keluarganya. Oleh sebab itu keluarga harus mencerminkan keteladanan dalam beribadah bagi anak-anak nya.

Dalam kondisi pandemic seperti ini, lingkungan keluarga sangat rentan terpapar wabah ini. Karena pada dasarmya wabah covid-19 ini dapat terjangkit pada siapa saja, dimana saja, dan kapan saja termasuk dalam lingkungan keluarga. Penyebaran wabah ini bisa saja berasal dari anggota keluarga atau orang tinggal satu atap dengan kita atau biasa disebut dengan klaster keluarga. Bermula dari salah satu anggota yang terlebih dahulu terpapar kemudian menularkannya pada anggota keluarga yang lainya.

Penyebab adanya klaster keluarga ini dikarenakan kurang berperan aktif dalam melaksanakan protokol kesehatan seperti membiarkan anaknya bermain di luar rumah tanpa menjaga jarak dan memakai masker, ketika habis bepergian tidak mencuci tangan sebelum masuk kedalam rumah, dan kontak langsung dengan orang yang memiliki gejala wabah tersebut. Untuk mengurangi atau mencegah klaster keluarga pada masa pandemi ini diperlukan penyuluhan, agar dapat meningkatkan pengetahuan serta kesadaran bagi keluarga seperti bagaimana penyebaran covid-19, pentingnya memakai masker, mencuci tangan dengan air mengalir, serta menjaga jarak. Mencuci tangan dengan air mengalir lebih efektif dalam memutuskan mata rantai wabah ini dari pada menggunakan hand sanitizer (Gustomy 2020). Klaster ini sangat berbahaya sebab memiliki resiko penularan yang cepat saat salah seorang 
anggota keluarga yang terpapar wabah ini. Sehingga, dapat menular ke anggota keluarga lain yang tinggal bersama.

Demi mencegah klaster keluarga saat pandemi, kepala keluarga memiliki peran aktif dalam mendisiplinkan seluruh anggota keluarga. Kunci awal agar klaster keluarga aman dari paparan wabah ini merupakan disiplin. Peran kepala keluarga merupakan suatu hal yang dapat membantu pemerintah dalam memutuskan mata rantai penyebaran covid-19 (Nasution et al. 2021). Hal ini dikarenakan kepala keluarga adalah panutan dalam keluarga atau biasa disebut dengan pemimpin keluarga yang memiliki kekuasaan tertiggi untuk membuat peraturan agar seluruh anggota keluarganya selalu mematuhi protokol kesehatan yang diterapkan oleh pemerintah. Dengan demikian, kepala keluarga harus bisa memberi contoh yang baik, menerapkan gaya hidup sehat. Seperti membiasakan diri untuk mencuci tangan dengan air mengalir, berdiam diri dirumah, tidak keluar rumah tanpa adanya kepentingan yang mendesak, jika ada kepentingan yang mendesak, ketika tiba dirumah segera mandi dan ganti pakaian. Kedisipilan yang diterapkan dapat mendorong anggota keluarga lainya untuk menaati peraturan yang dibuat oleh kepala keluarga.

\section{Urgensi Dakwah di Lingkungan Keluarga dalam Menyikapi Pandemi}

Dalam kondisi pandemi seperti ini keluarga sangat berpengaruh dalam menyikapi kebijakan pemerintah dalam memutuskan mata rantai penyebaran covid-19. Dalam kebijakan untuk berdiam diri dirumah sebuah keluarga seharusnya dapat mengambil hal positif seperti saling memperbaiki diri untuk mendekatkan diri kepada Allah swt. Selanjutnya menanamkan nilainilai keimanan terhadap anak. Namun tidak bisa di pungkiri, tidak semua keluarga dapat mengambil hal positif dalam kondisi seperti ini. Dengan berdiam diri dirumah malah terjadi konflik antara kedua orangtua (Pohan 2021). Kondisi pandemi seperti ini sangat berdampak bagi finansial sebuah keluarga, ada keluarga yang tidak bisa menyelesaikan konflik tersebut dengan berujung perceraian. Namun ada juga keluarga yang mempertahankan keutuhan keluarga demi masa depan anak-anaknya. Oleh karena itu keluarga yang tergolong mampu bahkan pemerintah untuk memberi bantuan kepada mereka yang finansialnya terganggu akibat dampak dari pandemi.

Sebagai umat Islam yang bertauhid kita tidak boleh bersikap keakuan, hanya memperdulikan diri sendiri dan menganggap bisa hidup tanpa bantuan siapapun. Kita tidak boleh membiarkan saudara-saudara kita putus dari sekolah hanya karena sulitnya ekonomi akibat dampak pandemi (Wirman and Bonjol 2013). Dilarang bagi sesama muslim bersikap masa bodoh dan membiarkan keluarga kita menukarkan iman dan agama Islam mereka dengan beras, mie instan, pakaian dan uang. Jika sebagai anggota keluarga kita membiarkan mereka kufur atau murtad karena penghimpitan kemiskinan maka dampak berdosa juga akan kita ambil bagian. Inilah makna dakwah yang lebih luas.

Pada konteks pandemi Covid-19, sudah seharusnya peran keluarga terutama orang tua menyadarkan kepada seluruh anggota keluarganya agar menekankan nilai-nilai keimanan bahwa virus Covid-19 merupakan makhluk Allah. Tidak akan ada yang mampu berkuasa menciptakannya, menyebarkanya, dan menghilangkannya, kecuali Allah swt. Oleh sebab itu, manusia diwajibkan untuk senantiasa berdoa dan memohon agar dijauhkan dari wabah Covid-19 dengan diiringi ikhtiar mencegah diri dari berbagai hal yang dapat menimbulkan terjangkitnya Covid-19 (Akbar 2021). Setelah itu, menekankan untuk bertawakal kepada Allah dengan memiliki keyakinan bahwa Allah maha segalanya dalam menghentikan pandemi Covid-19.

Uqbah bin Amir. Dari Abi Umamah dari Uqbah bin Amir, berkata: Aku berkata: "Wahai Rasulullah apa penyebab keselamatan?" Rasulullah bersabda: "Tahanlab olehmu lisanmu, menetaplah di rumabmu, tangisilah kesalahan-kesalahanmu." (HR.Al-Tirmidhi). Hadis lain riwayat Imam alBukhari dari Sa'dan: Sesungguh Nabi saw telah bersabda: 'Iika kalian mendengar Tha'un (wabah 
penyakit menular) berjangkit di suatu negeri, maka janganlah kamu masuk ke negeri itu, dan apabila kamu berada dalam negeri itu maka janganlah kamu keluar darinya." (HR. Al-Bukhari) (Qudsy and Sholahuddin 2020).

Dari hadis pertama dapat diketahui bahwa hal pertama yang dilakukan keluarga adalah tidak membicarakan wabah secara terus-menerus. Secara kontekstual, membicarakan wabah dapat dilakukan secara langsung maupun lewat media massa, seperti siaran televisi, radio, dan sosial media. Dampak yang ditimbulkan karena hal ini adalah akan timbul rasa kecemasan dan kekhawatiran masyarakat terhadap wabah ini (Junaedi et al. 2020). Timbulnya rasa kecemasan dan kekhawatiran dapat menyebabkan imun seseorang lemah sehingga mudah terserang penyakit. Selain itu, pembatasan membicarakan wabah ini agar masyarakat tetap bahagia dalam menjalani hidup. Sehingga dalam hadis tersebut Rasulullah saw memerintahkan untuk menahan lisan, kemudian hal kedua yang dilakukan adalah berdiam diri di rumah.

Selaku orangtua memberikan kesan atau sugesti positif mengenai pandemi Covid-19, dimana ada hal baik yang sedang Allah rencanakan dari dampak pandemi bukan memberi ketakutan berupa informasi-informasi yang berlebihan seperti banyaknya korban yang meninggal akibat Covid-19 (Freiling et al. 2021). Hoax berupa serangan dari asing dengan tujuan ambil alih negara serta berita-berita mengerikan dampak tekanan sosial bagi keluarga yang dinyatakan positif. Orang tua juga harus dapat menjadi sumber bertanya anak-anaknya untuk memahami informasi-informasi yang merusak akidah terutama mengenai vaksin seperti beberapa golongan tertentu yang meyatakan dengan lantangnya bahwa "barang siapa yang melakukan vaksin sejatinya orang tersebut adalah pengikut dajjal." Ada juga golongan yang lain menyatakan bahwasanya barang siapa-siapa saja yang vaksin maka mereka telah kafir.

Pentingnya peranan orang tua mengkomunikasikan kepada keluarga dengan sudut pandang yang benar. Maka orangtua juga dituntut memiliki ilmu yang cukup atau ada sumber bertanya yang dipercaya. Selain golongan atau kelompok orang yang meyatakan terangterangan tentang kafir atau pengikut dajjal ada juga yang menyatakan covid-19 ini adalah serangan dari kaum jin. Jadi cara melawan jin harus dengan jin. Hal-hal seperti ini adalah halhal yang sangat-sangat merusak akidah dan komunikasi yang keliru (Syaipudin 2020). Belum lagi munculnya dukun-dukun atau orang-orang pintar yang membuka jasa pengobatan jin arena covid-19.

Tidak hanya masyarakat yang ada di pedalaman atau di desa, tauhid dalam keluarga juga menyerang keluarga-keluarga di kota terutamama prusahan-prusahaan minuman. Susu atau minuman dengan ekstrak vitamin misalnya, juga mengkampanyekan (mengkomunikasikan) info yang salah. Mereka hanya peduli dengan nilai jual produknya, sehingga masyarakat menganggap dengan meminum produk-produk mereka maka dapat mencegah diri dari Covid-19 (Indasari and Anggriani 2020). Kejadian lain, ada pula isu yang beredar di masyarakat bahwa produk tertentu (susu), mampu mematikan anti virus yang terletak di vaksin. Selanjutnya, produk itu menjadi laris manis atas komunikasi yang dipopulerkan oleh marketing. Ketakutan masyarakat terhadap vaksinasi dimanfaatkan untuk meraup laba melalui media komunikasi yang subjektif. Jadi peran orang tua sangat-sangat besar terhadap membimbing anak-anaknya dari pada berbagai komunikasi di masa Covid-19 terutama vaksin.

Pada belahan dunia juga ada yang menuhankan Covid-19, salah satunya adalah negara India. India dikenal negara yang mayoritasnya pecaya lebih dari satu tuhan. Mereka meyakini kepercayaan terhadap Dewa-dewa. Jumlah pasien positif Covid-19 di India yang sangat meledak menjadi pemicunya, dimana mereka menganggap Covid-19 ini tidak dapat di lawan dengan vaksin ataupun lockdown. Maka dengan menyembah akan membuat Covid-19 yang tadi yang menyerang manusia berubah fungsi (menyembuhkan) (Wahyu et al. 2021). Beritaberita seperti ini sangat-sangat berbahaya bagi akidah anak. Apa lagi anak yang mendapatkan berita tersebut langsung menelanya bulat-bulat. 
Seperti yang kita ketahui, media Indonesia adalah media yang penekanan informasinya berada pada kepentingan rating atau follower. Artinya mereka tidak begitu peduli terhadap berita atau informasi yang mereka sebarkan akan berdampak pada akidah anak-anak di negaranya. Bagi mereka, berita yang bagus adalah berita yang menghasilkan viewer terbanyak. Apa lagi negara Indonesia ini adalah negara yang dimana informasi negatif sangat cepat viral dari pada informasi baik (Gustomy 2020). Maka salah satu peran orangtua untuk mengurangi dampak rusaknya tauhid dalam keluarga juga dengan membatasi penggunaan Televisi dan smartphone. Membatasi disini bukan berarti tidak membolehkan anak-anak menonton TV dan smartphone, melainkan memberi edukasi; mana siaran yang layak atau tidak. Peran smartphone juga lebih berbahaya dari pada televisi saat ini. Grup-grup yang menyebarkan berita-berita hoax sangat cepat menyebar. Maka saling keterbukaan anak terhadap orang tua (komunikasi) juga sangat penting.

Disarankan kepada orang tua agar dapat mendidik anaknya dengan cara asertif, yaitu cara mendidik dengan pendekatan, pendekatan sebagai kawan dengan masuk kedunianya. Asertif ini berada pada posisi di antara pembiaran dan otoriter (Aswat and Rahman 2021). Contoh: ketika anak telat sholat lima waktu dikarenakan sesuatu hal maka cara asertif adalah bukan cara dengan memarahi langsung atau memaki-maki si anak, melainkan menayakan dengan pendekatan soft selling; "Ayo nak! Apa yang bisa Bapak dan Ibu bantu agar sholatnya biar gak. telat lagi?" Sehingga si Anak tidak tertekan. Pembiaran juga sama bahayanya dengan otoriter, ketika orang tua malas atau enggan komunikasi menasehati anak maka pemikiran yang liarlah yang akan muncul. Jadi cara efektif menghaapi rusaknya tauhid adalah dengancara asertif. Ini adalah komunikasi yang sangat dianjurkan demi kebaikan bersama.

Selain peran orang tua, sangat penting dalam membimbing anak-anaknya terhadap menyikapi tauhid akibat covid-19, orangtua sendiri juga dapat memilih dengan cerdas mana organisasi-organisasi atau pengajian yang benar (Dessy Asnita 2021). Bukan pengajian yang malah keluar dari zona tauhid tetapi malah zona radikalisme yang didapat. Apabila organisasi atau pengajian tersebut sangat keras menyatakan bahwa yang pecaya sama covid-19 adalah kafir itu sangat mudah membedakanya. Akan tetapi, ada komunitas pengajian dan kelompok tertentu yang melakukan pendekatanya bertahap, mulai dari mengajak pengajian yang awalawalnya benar-benar baik tetapi lama kelamaan malah digiring ke kepetingan yang merusak akidah, trutama prihal tauhid, pemerintah serta radikalisme.

Jika orang tua yang sudah terpapar dengan rusaknya tauhid maka orang tua tersebut akan menjadi katalisator pemhaman radikal tauhhid kepada anak-anaknya, tetanggatetangganya serta saudara-saudaranya. Oleh karena itu pentinya punya prinsip 'Belajar sepanjang Hayat' agar diri pribadi serta anak-anak selamat dari pada rusaknya akidah dalam tauhid di masa pandemi ini.

\section{PENUTUP}

Pandemi Covid-19 berdampak pada berbagai lini mulai dari wilayah kesehatan, ekonomi, pariwisata, kebijakan publik, dan pergerakan arah politik. Pandemi Covid-19 juga sering kali dijadikan pengalihan isu atas berbagai kepentingan oknum tertentu demi memperoleh keuntungan subjektif. Berbagai komunikasi publik terkait pandemi memiliki dua aliran besar. Pertama, komunikasi positif yang mendukung program pemerintah jika itu dianggap baik dan bermanfaat bagi penanggulangan wabah pandemi Covid-19. Pihak ini biasanya akan melaksanakan berbagai kebijakan seperti lockdown, PSBB, sosial distancing, protokoler kesehatan, dan vaksinasi.

Kedua, adalah komunikasi negatif yang menolak berbagai program pemerintah atas kepentingan politik (kontra dengan pemerintah saat ini). Biasanya, kalangan ini akan menyebarkan hoaks dan ujaran kebencian terhadap kebijakan penanganan Covid-19 yang 
dijalankan pemerintah. Kalangan ini tidak melihat informasi secara objektif, melainkan mencari-cari celah untuk menyerang berbagai kelemahan dalam program pemerintah guna mempengaruhi masyarakat luas. Akibatnya, masyarakat selaku konsumsi informasi cenderung lebih mendukung komunikasi bagian kedua ini. Alasannya, tentu saja karena nilai-nilai kebencian lebih mudah terserap karena situasi sedang tidak kondusif.

Komunikasi yang bersifat penengah adalah solusi dari gesekan antara dua kubu di atas. Tidak sedikit hoaks dan ujaran kebencian terhadap penanganan Covid-19 melibatkan dimensi agama dan tauhid. Tentu saja, motif ini sangat popular dilakukan karena menghemat dana dan anggaran. Pelaku politis hanya perlu mensosialisasikan berita-berita palsu dengan melibatkan embel-embel agama. Maka dari itu, filterisasi komunikasi negatif paling ideal jika dimulai pada lingkungan keluarga. Keluarga adalah wahana yang paling dekat dengan setiap individu, dan dapat dengan mudah mengontrol aktivitas satu sama lain sehingga terhindar dari pengaruh hoaks dan ujaran kebencian. Oramgtua diharapkan cerdas dalam memahami berita-berita yang beredar, orangtua juga diminta sigap dalam memantau perkembangan anaknya ketika menjadi sasaran komunikasi public dan politik.

Bagi peneliti selanjutnya, bila ingin menulis dan mengkaji tema tersebut, disarankan untuk melakukan penelitian lapangan yang melibatkan informan dari kalangan public, pemerintah, dan pihak yang kontra dengan pemerintah. Model penelitian tersebut akan lebih memungkinkan menemukan hasil yang objektif sesuai dengan perkembangan pandemic Covid19 yang terjadi di Indonesia. Selain itu, disarankan juga melibatkan berbagai stakeholder sehingga penelitian selanjutnya akan lebih maksimal dan mendapat dukungan dana yang memadai.

\section{DAFTAR PUSTAKA}

Akbar, Syarifuddin. 2021. "MEDIA KOMUNIKASI DALAM MENDUKUNG PENYEBARLUASAN INFORMASI PENANGGULANGAN PANDEMI COVID-19.” 2(1):10.

Anzaikhan, M. 2019. "Hakikat Administrasi Pemerintahan Islam.” Al-Ijtima i: International Journal of Government and Social Science 5(1):56-80. doi: 10.22373/jai.v5i1.465.

Anzaikhan, Muhammad. 2021. "PEMAHAMAN PLURALISTAS ULAMA DAYAH DAN DAMPAKNYA TERHADAP PEMIKIRAN ISLAM DI ACEH.” Abrahamic Religions: Jurnal Studi Agama-Agama 1(2):202. doi: 10.22373/arj.v1i2.11214.

Aswat, Hazarul, and Arif Rahman. 2021. "KEWAJIBAN SUAMI MEMBERI NAFKAH DALAM KOMPILASI HUKUM ISLAM.” 5(1):12.

Baidowi, Ahmad, Ahmad Salehudin, Abdul Mustaqim, Saifuddin Z. Qudsy, and Nurul Hak. 2021. "Theology of Health of Quranic Pesantren in the Time of COVID-19." HTS Teologiese Studies / Theological Studies 77(4). doi: 10.4102/hts.v77i4.6452.

Dessy Asnita, Fika Andriana, Agustinar \&. 2021. "Istri Bergaji: Analisis Peran Wanita Bekerja Dalam Meningkatkan Ekonomi Keluarga." Al-Qadha: Jurnal Hukum Islam dan Perundang-Undangan 8(1):13-32. doi: 10.32505/qadha.v8i1.2800.

Fahiza, Zihan and Siti Nur Zalikha. 2021. "Kebijakan Pemerintah dalam Kegiatan Shalat Berjamaah di Masa Pandemi Covid-19." Jurnal Riset dan Pengabdian Masyarakat 1(1):4855. doi: 10.22373/jrpm.v1i1.629.

Freiling, Isabelle, Nicole M. Krause, Dietram A. Scheufele, and Dominique Brossard. 2021. "Believing and Sharing Misinformation, Fact-Checks, and Accurate Information on 
Social Media: The Role of Anxiety during COVID-19." New Media \& Society 146144482110114. doi: 10.1177/14614448211011451.

Gustomy, Rachmad. 2020. "Pandemi ke Infodemi: Polarisasi Politik dalam Wacana Covid-19 Pengguna Twitter." JIIP: Jurnal Ilmiah Ilmu Pemerintahan 5(2):190-205. doi: 10.14710/jiip.v5i2.8781.

Indasari, Fera, and Ida Anggriani. 2020. "KRISIS KOMUNIKASI PADA MASA PANDEMI COVID-19 (Studi Kasus Pemberitaan Penyebaran Covid-19 melalui Udara)." Profesional: Jurnal Komunikasi dan Administrasi Publike 7(1):1-11. doi: 10.37676/professional.v7i1.1086.

Junaedi, Jujun, Mukhlis Aliyudin, and Dede Sutisna. 2020. "KONFLIK INTERPRETASI FATWA MUI DALAM PELAKSANAAN IBADAH SELAMA PANDEMI COVID-19." 6:15.

Kastolani, Kastolani. 2020. "Understanding the Delivery of Islamophobic Hate Speech via Social Media in Indonesia." Indonesian Journal of Islam and Muslim Societies 10(2):247-70. doi: 10.18326/ijims.v10i2.247-270.

Mansyur, Muhammad. 2020. "Model Literasi Digital untuk Melawan Ujaran Kebencian di Media Sosial." 22(2):18.

McGuire, Amy L., Mark P. Aulisio, F. Daniel Davis, Cheryl Erwin, Thomas D. Harter, Reshma Jagsi, Robert Klitzman, Robert Macauley, Eric Racine, Susan M. Wolf, Matthew Wynia, Paul Root Wolpe, and The COVID-19 Task Force of the Association of Bioethics Program Directors (ABPD). 2020. "Ethical Challenges Arising in the COVID-19 Pandemic: An Overview from the Association of Bioethics Program Directors (ABPD) Task Force." The American Journal of Bioethics 20(7):15-27. doi: 10.1080/15265161.2020.1764138.

Mushodiq, Muhamad Agus, and Ali Imron. 2020. "Peran Majelis Ulama Indonesia Dalam Mitigasi Pandemi Covid-19 (Tinjauan Tindakan Sosial dan Dominasi Kekuasaan Max Weber)." S ALAM: Jurnal Sosial dan Budaya Syar-i 7(5). doi: 10.15408/sjsbs.v7i5.15315.

Nasruddin, Rindam, and Islamul Haq. 2020. "Pembatasan Sosial Berskala Besar (PSBB) dan Masyarakat Berpenghasilan Rendah." SALAM: Jurnal Sosial dan Budaya Syar-i 7(7). doi: 10.15408/sjsbs.v7i7.15569.

Nasution, Muhammad Arsad. 2020. "EFEKTIVITAS RUKHSHAH DALAM PELAKSANAAN IBADAH MASA PANDEMI COVID-19.” 6(1):16.

Nasution, Nurul Hidayah, Arinil Hidayah, Khoirunnisa Mardiah Sari, Wirda Cahyati, Mar'atun Khoiriyah, Riska Putriana Hasibuan, Ahmad Afandi Lubis, and Andi Yahya Siregar. 2021. "GAMBARAN PENGETAHUAN MASYARAKAT TENTANG PENCEGAHAN COVID-19 DI KECAMATAN PADANGSIDIMPUAN BATUNADUA, KOTA PADANGSIDIMPUAN.” 6(1):8.

Ngadi, Ngadi, Ruth Meliana, and Yanti Astrelina Purba. 2020. "DAMPAK PANDEMI COVID-19 TERHADAP PHK DAN PENDAPATAN PEKERJA DI INDONESIA.” Jurnal Kependudukan Indonesia 43. doi: 10.14203/jki.v0i0.576.

Paisal, Jon. 2021. "Peran Dakwah Dalam Keluarga Dan Relevansinya Bagi Pembentukan Karakter Anak." Al-Qadha: Jurnal Hukum Islam dan Perundang-Undangan 8(1):50-66. doi: 10.32505/qadha.v8i1.2726. 
Pohan, Muslim. 2021. "Fenomena dan Faktor Perkawinan Semarga." Al-Qadha: Jurnal Hukum Islam dan Perundang-Undangan 8(1):67-84. doi: 10.32505/qadha.v8i1.2088.

Qudsy, Saifuddin Zuhri, and Ahmad Sholahuddin. 2020. "Kredibilitas Hadis dalam COVID19: Studi atas Bażl al-Mā’ūn fi Fadhli al-Thāun karya Ibnu Hajar al-Asqalany.” AL QUDS : Jurnal Studi Alquran dan Hadis 4(1):1. doi: 10.29240/alquds.v4i1.1476.

Rahmawati, Dwi, Raden Aswin Rahadi, and Almira Devita Putri. 2021. "The Current State of Property Development in Indonesia During the Covid-19 Pandemic." International Journal of Innovation 15(7):19.

Roni, Muhammad, and M. Anzaikhan. 2021. "Pembentukan Keluarga Shaleh Dalam Komunikasi Islam: Studi Komparasi Penafsiran Al-Qur'an.” AL-HIKMAH: Media Dakwah, Komunikasi, Sosial dan Budaya 12(1):51-61. doi: 10.32505/hikmah.v12i1.2825.

Saputera, Abdur Rahman Adi. 2020. "MENELISIK DINAMIKA DAN EKSISTENSI FATWA MUI SEBAGAI UPAYA MITIGASI PANDEMI COVID-19." Tabkim Jurnal Peradaban dan Hukum Islam) 3(2):59-78. doi: 10.29313/tahkim.v3i2.6569.

Sarnoto, Ahmad Zain, Rachmat Hidayat, and Sri Tuti Rahmawati. n.d. "Kegiatan \& Program Dakwah selama Pandemi (Studi Lapangan Masjid Jami’ Al Azhar Jakapermai, Kota Bekasi, Jawa Barat, Indonesia)." 9.

Serfontein, Bernice. 2021. "Imagining a New 'Abnormal' amidst COVID-19: Seeking Guidance from Evolutionary Anthropology and Theology." HTS Teologiese Studies / Theological Studies 77(3). doi: 10.4102/hts.v77i3.6519.

Setiawan, Agus. 2016. "KONSEP PENDIDIKAN TAUHID DALAM KELUARGA PERSPEKTIF PENDIDIKAN ISLAM.” 1(2):22.

Sonata, Depri Liber. 2015. "METODE PENELITIAN HUKUM NORMATIF DAN EMPIRIS: KARAKTERISTIK KHAS DARI METODE MENELITI HUKUM." FLAT JUSTISIA:Jurnal Ilmu Hukum 8(1). doi: 10.25041 / fiatjustisia.v8no1.283.

Syaipudin, Latif. 2020. "Efektifitas Media Komunikasi di Tengah Pandemi: Respon Gugus Tugas Percepatan Penanganan Covid-19 Kabupaten Tulungagung." Kalijaga Journal of Communication 1(2):165-78. doi: 10.14421/kjc.12.06.2019.

Wahyu, Agung Minto, Afifah Chusna Az Zahra, Muhammad Iqbal Fakhrul Firdaus, and Aryudho Widyatno. 2021. "Perilaku Panic Buying Mengiringi Kemunculan COVID19? Sebuah Studi pada Awal Pandemi di Indonesia." Humanitas (Jurnal Psikologi) 5(1):76-98. doi: 10.28932/humanitas.v5i1.3347.

Wirman, Eka Putra, and IAIN Imam Bonjol. 2013. "THE FALLACIES OF HARUN NASUTION'S THOUGHT OF THEOLOGY.” 07(02):22. 